\title{
Kadro Dergisi’nde Planlama Anlayışı
}

\section{Concept of Planning in Kadro Journal}

\author{
Veysel Erat ${ }^{\mathrm{a}, *}$ \\ ${ }^{a}$ Dr. Öğr. Üyesi, Bitlis Eren Üniversitesi, İ̈BF, Kamu Yönetimi Bölümü, 13000, Bitlis/Türkiye. \\ ORCID: 0000-0002-0735-5432
}

\section{MAKALE BİLGİİ}

Makale Geçmişi:

Başvuru tarihi: 26 Nisan 2017

Düzeltme tarihi: 11 Temmuz 2017

Kabul tarihi: 20 Temmuz 2017

\section{Anahtar Kelimeler: \\ Kadro Dergisi \\ Kadrocular \\ Kadro Hareketi \\ İnk1lap \\ Plan}

\section{ARTICLE INFO}

\section{Article history:}

Received 26 April 2017

Received in revised form 11 July 2017

Accepted 20 July 2017

\section{Keywords:}

Kadro Journal

Kadrocans

Revolution

Plan

\section{ÖZ}

Türkiye'nin 1930'larda geliştirdiği özgün plan pratiği dünyanın ilk örnekleri arasındadır. Bu dönemde yapılan iki plan sanayiyi merkeze alan ve bu nedenle kapsam itibariyle sınırlı sektör programlarıdır. Pratikte böyle olmasına rağmen anlayış olarak plan oldukça geniş bir çerçeve de ele alınmıştır. Bunun önemli bir örneği Kadro Dergisi yazılarıdır. Bu bağlamda çalışmada Kadro Dergisi'nin plan anlayışı incelenmiştir. Kadro Dergisi'nin tüm sayıları taranarak planlama konusu önem, anlam, amaç ve kapsam şeklinde bir sınıflandırmayla analiz edilmiş̧ir. Sonuç olarak, çalışmada 1960'larda başlayan kapsamlı kalkınma planlarından çok daha önce bu niteliği içerisinde barındıran bir anlayışın Kadro Dergisi'nde olduğu ortaya konmuştur.

\section{A B S T R ACT}

The original plan practice developed by Turkey in the 1930s is among the first examples of the world. The two plans made in this period are the sector programs that got the industry to the center and therefore are limited in scope. Despite this fact in practice, as a concept, the plan has been dealt with as a broad framework. An important example of this is the writings of Kadro Journal. In this context, the concept of the Kadro Journal's plan has been examined. All the figures of Kadro Journal were scanned and the plan topic was analyzed with a classification in terms of importance, meaning, purpose and scope. As a result, it has been revealed that an understanding of this quality was already in the Kadro Journal before the comprehensive development plans that started in the 1960s.

\section{Giriş}

Türkiye'de ilk planlama girişimi, Kadro Dergisi'nin çıkarıldığı 1930'lu yıllara rastlamaktadır. Devletçi dönem olarak bilinen 1930'larda planlama anlayışının hem iktidar gündeminde yer alması hem de fikri açıdan ele alınması döneme özgü bazı gelişmelerin sonucudur. Öncelikle 1929 Dünya Ekonomik Krizi, Türkiye'nin içe dönük, devlet öncülüğünde hızlı sanayileşme politikasını benimsemesinin zeminini hazırlamıştır. Kriz bir taraftan ihraç pazarlarında daralmaya ve buna bağlı olarak tarımsal ürünlerin fiyatlarında düşüşe neden olurken, diğer taraftan temel mal ithalatında ağır kısıtlamalar getirmiştir. Bu durum ihraç ürünleri için iç pazar meydana getirmeyi ve ithal edilemeyen malların yerli üretimini gerekli kılmıştır. Bu görevi yerine getirecek yerli burjuvazinin bulunmayışı devleti anılan faaliyetlerin temel aktörü yapmış ve devletçilik bir zorunluluk olarak doğmuştur (Gülalp, 1993: 30-31). Devletçilikle ilgili yapılan yorumların kapsamı geniş olmasına rağmen ortak oldukları nokta devletçiliğin planlı olmasıdır (Tekeli ve İlkin, 2009: 134). Planlama anlayışını geliştiren ikinci önemli etki, Sovyetler Birliği'nin planlamayı benimsemesi ve buna bağlı olarak hızlı bir kalkınma sürecine girmesidir (Kansu, 2004: 27).

\footnotetext{
* Sorumlu yazar/Corresponding author.

e-posta: veyselerat@hotmail.com
} 
Anılan gelişmeler planlama ve plan anlayışına fiili ve fikri olarak yansımıştır. Fiili olarak, dünyada ilk planlama deneyimlerinden biri olarak kabul edilen ve tüketim malları üretiminde artış sağlama amacında olan Birinci Beş Yıllık Sanayi Planı bu koşullar altında doğmuştur (Soyak, 2013: 129). 1932'de hazırlanan plan 1934'te kabul edilip uygulamaya konulmuştur. Planda krizin dünyanın geri kalmış ülkeleri için bir silkinme firsatı tanıdığı ve bunun yolunun sanayileșme ve planlama olduğu belirtilmiştir (İnan, 1972; Günçe, 1981: 117). Birinci plan uygulamadayken 1936'da ikinci planın hazırlıkları başlamış ve 1938'de kabul edilmiştir. Ancak İkinci Dünya Savaşı planın uygulanmasına izin vermemiştir. İçerisinde Kadro Dergisi'nin önemli yazarlarından biri olan Şevket Süreyya Aydemir'in de olduğu bazı düşünürler, bu planları makro planlama anlayışı ile ilişkisinin olmadığından hareketle "sektörler programı", "yatırım projeleri listesi", "proje koleksiyonu" şeklinde tanımlamıştır (Sezen, 1999: 143). Her iki plan incelendiğinde ve 1960'ların kalkınma planlarıyla karşılaştırıldığında planların sınırlı olduğu görülmektedir (İnan, 1972, 1989). Ancak planın fikri boyutu daha kapsamlıdır. Diğer bir ifadeyle, yapılan planlar makro plan özelliği taşımazken, konuyu ele alan çalışmalarda plan anlayışı daha kapsamlı tasavvur edilmiştir.

Plan konusuna önem verilen ve içerisinde detaylı incelemelerin bulunduğu Kadro Dergisi bunların başında gelmektedir. Kadroculara göre plan, inkılapların aşamasını karakterize eden önemli bir olgu ve devletin sürekliliğinin temeli olan iktisadi koşulların aracıdır (Hayrettin, 1933: 57 58; Aydemir, 1932f: 12). İnkılapların derinleşmesi ve benimsenmesi amacıyla çıkarılan derginin esas sorunsalı bu değildir, ancak planlamaya savunulan devletçi görüş ve inkılapların devamlılı̆̆ noktasında merkezi bir rol atfedildiğinden sıklıkla incelenmiştir. $\mathrm{Bu}$ bağlamda çalışmanın amacı Kadro Dergisi'nde plan anlayışının incelemesidir. Konuya ele alan doğrudan bir çalışma bulunmamakla birlikte, dönem ya da konu incelemeleri gereği Kadro Dergisi'nin planlama anlayışına değinen çalışmalar bulunmaktadır. Tekeli-İlkin (2009) "Uygulamaya Geçerken Türkiye'de Devletçiliğin Oluşumu" isimli çalışmalarında Kadro Dergisi'yle ilgili başlıkta derginin devletçilik anlayışı ekseninde plan anlayışını incelemişlerdir. Ayrıca Küçük (1981) “Türkiye'de Plan Kavramının Gelişimi Üzerine" başlıklı makalesinde Kadrocuların plan kavramına katkısı üzerinde durmuştur. Her iki çalışmada önemli çıkarımlarda bulunulmuştur. Ancak esas sorunsalları bu olmadığından konu tüm boyutlarıyla incelenmemiştir. $\mathrm{Bu}$ çalışmada Kadrocuların plan anlayışı Kadro Dergisi'nin tüm sayıları taranarak analiz edilmeye çalışılacaktır. Çalışma ağırlıklı olarak literatür taraması ve arşiv araştırması yöntemini benimsemiştir. Üç ana bölümde tasarlanan çalışmada ilk olarak, Kadrocuların plan anlayışını şekillendiren temel olguların bilinmesi açısından Kadro hareketi incelenecektir. İkinci olarak, derginin kuruluş ve kapanışı ile dergide genel olarak ele alınan konular üzerinde durulacaktır. Son bölümde Kadro Dergisi'nde planlama anlayışı önem, anlam, amaç ve kapsam boyutlarıyla ortaya konulmaya çalışılacaktır.

\section{Kadro Hareketi}

Kadro hareketi, aylık yayımlanan Kadro Dergisi'nde birleşen yazarların yürüttükleri düşünce akımıdır. Derginin ilk sayısı 1932'de çıksa da burada savunulan görüşler ilk defa Şevket Süreyya Aydemir'in 15 Ocak 1931'de, Ankara'da Türkocakları genel merkezinde, “İnkılabın İdeolojisi” başlığını taşıyan konuşmasıyla ortaya çıkmıştır (Kepkep, 1983: 43). Konferanstan sonra hareketli bir şekilde tartışılmaya başlanan görüşler, Kadro Dergisi'nin ideolojik çerçevesini oluşturmuştur. Daha sonra bu metin Aydemir' in "İnkılap ve Kadro" adlı kitabında bazı ekleme ve çıkarmalarla yayımlanmıştır (Yanardağ, 2012: 113; Kepkep, 1983: 43). Anılan kitapta "İnkılabımızın İdeolojisi" başlığında Aydemir, Türk inkılabının taşımış olduğu temel fikir prensiplerini ve ulusötesi değerleri şu şekilde saymaktadır:

(i) Batı ülkelerinde toplumsal çelişkilerin ve sınıf kavgalarının milletin bekasını tehdit ettiği bir zamanda Türk inkılabı imtiyazsız ve sınıfsız bir bağımsızlık sloganı ortaya atmıştır.

(ii) Teknik gelişmelerin neden olduğu toplumsal çelişkilerin, gelişimin kendisine engel olduğu ya da bu gelişmenin toplumu değersiz kıldığı ve ahlaki çöküntü meydana getirdiği bir dönemde Türk inkılabı, şiddetli toplumsal reaksiyonlardan korunmak için yüksek tekniğin planlı bir devlet kontrolü ile benimsenmesini öngörmüştür.

(iii) Boyun eğen ve eğilen devletler düzeni yerine her biri kendi içinde siyasi ve iktisadi açıdan birlik, aralarında ise özgür ve eşit milletler düzenini savunmuştur (Aydemir, 2011: 81-82).

Aydemir'e (2011) göre dünyanın yeniden bir başka düzen altında kurulmasını amaçlayan inkılapçıların bir takım tarihi misyonu bulunmaktadır. Bunlar, inkılabın özgün fikirlerinin belirli, düzenli, gerçekçi, somut prensipler şeklinde düzenlemek; fikir sistemini temsil eden değil fikir sistemine dayanan bir inkılap yapısını oluşturmak; inkılabın temsil ettiği fikirleri ideoloji olarak benimsetmek; inkılabın maddi ve manevi bütün kurumlarını oluşturmak ve bunu sonraki nesillere bırakmaktır. Bunu gerçekleştirecekler bir şef veya parti sisteminde varlık kazanacak inkılapçı bir kadrodur. Bu bağlamda kadro kavramı ile milli kurtuluş ve buna bağlı bir şekilde inkılap hareketi içinde bulunan bir ülkenin önderler ve idealistler topluluğu kastedilmektedir. Halkın yararına yöneten ve halkçı iktidarlar ve şahsiyetler olarak nitelendirilen kadronun başlıca amacı, ülkenin sömürge altına alınmasının önüne geçmek ve ileri tekniğe sınıfsız bir düzen ile ulaşmak olarak belirtilmiştir (Aydemir, 2011: 8384, 218-219).

Kadrocuların birçoğunun sahip olduğu sosyalist geçmişleri Türk inkılabının ve milli kurtuluş hareketinin teorik çerçevesini formüle eme çabalarına yansımış ve toplumsal ve siyasi analizlerinde etkileri görülmüştür (Karlı, 2015: 142). Bu nedenle bazı çevreler kadrocuları komünist, milliyetçi komünist, nasyonel sosyalist gibi sıfatlarla nitelemişlerdir (Aydemir, 1933a: 5). Ancak Marxist çevre de kadrocuları marksizme zarar verdikleri gerekçesiyle faşistlikle suçlamışlardır (Orhan, 2009: 144). Bunların yanı sıra sosyal faşist, neo-hitlerist, anarşist ve nihilist gibi suçlamalara da maruz kalmışlardır (Aydemir, 1933a: 5). Ancak kadro hareketinin ideoloğu olan Aydemir, kendisi için "kopması her ne kadar zor olsa da" komünist bir ihtilal bağlılığından devletçi bir iktisat görüşünü benimsediği bir fikri değişim geçirdiğini ifade etmiştir (Demirci, 2006: 38). Vedat Nedim Tör kadrocuların benimsedikleri dünya 
görüşünü Marxizmden uzaklaşmanın bir sonucu olarak ifade etmiştir (Kazancı, 2009: 47). Kadro yazarları her ne kadar sonuçları itibariyle farklılaşmış tarihsel materyalizmi yöntem olarak benimsese de beslenmiş oldukları kaynaklar birbirinden farklıdır ve hiçbir zaman referans aldıkları düşünceleri bütünüyle kabul etmemişlerdir. Aşağıda inceleneceği üzere dergide işlenen siyasal, kültürel, ekonomik ve sanatsal yazıların neredeyse tamamında ortak olan özellik bunların Türk inkılabı ile ilişkili olmasıdır (Tüysüzoğlu, 2011: 23). Bu bağlamda kadrocular ile ilgili Timur'un tespiti yerindedir. Kadrocular bir taraftan Marxist teorinin temeli olan diyalektik yöntemi farklı bir şekilde yorumlayarak inkılabın tezatsız toplum ilkesine ters düşmemiş, diğer taraftan yoğun devlet müdahaleciliğini ekonomide hâkim kılmaya çalışmıştır (Timur, 2013: 183$185)$.

\section{Kadro Dergisi}

Kadro Dergisi'nin kurucuları Şevket Süreyya Aydemir, İsmail Hüsrev Tökin, Burhan Asaf Belge, derginin imtiyaz sahibi olan Yakup Kadri Karaosmanoğlu ile yayın müdürü Vedat Nedim Tör'dür (Kadro, 1932). 1932-1934 yılları arasında 36 sayı olarak yayımlanan Kadro Dergisi'nin amac1, derginin ilk sayısında inkılap prensiplerinin bilinmesi, benimsenmesi ve benimsetilmesi olarak ifade edilmiştir (Kadro, 1932: 3). Derginin yazıları genel olarak sınıflandırıldığında dört konu üzerine yoğunlaştığı görülmektedir. Üzerinde en çok durulan konu milli iktisat yapısının oluşturulmasıdır. Bunun yanı sıra Şevket Süreyya Aydemir'in öncülüğünü yaptığı inkılap yazıları; Yakup Kadri Karaosmanoğlu'nun edebiyat yazıları ve son olarak bir dergi ya da hareket olarak Kadro’yu anlatan yazılar daha fazla yer almıştır.

Milli iktisat yapısının oluşturulması için birçok iktisadi konu incelenmiştir: toprak rejimi, sanayi, borçlanma, kredi, sermaye, dış ticaret, nüfus, iş ve işgücü piyasası, bütçe ve çeşitli sektörler (fındık, zeytin, tütün, afyon vb.). İktisadi konuların neredeyse tamamında devletçilik teması hâkimdir ve bu da inkılap ile ilişkilendirilmiştir. Derginin ideoloğu olarak kabul edilen Aydemir (Türkeş, 1999) doğrudan konu edindiği Türk inkılabının kendine münhasır yapısı, benimsenmesi ve yaygınlaşması konuları üzerinde dururken Karaosmanoğlu, yazdığı edebiyat yazılarıyla inkılabın kültürel boyutunu tasarlamaya çabalamıştır. Hareketi ya da dergiyi konu edinen yazıların da öne çıkan yönü Kadro'nun devam eden inkılaptaki rolü ve katkısıyla ilgilidir. Bu başliklarda yer edinmeyecek kişi ve konu incelemeleri de yine inkılapla ilgilidir. Netice itibariyle Kadro, yayın hayatı boyunca ilk sayıda belirtmiş olduğu çıkıș amacına hizmet etmiştir. Ancak kadrocular kendilerini lider grup ile halk arasında köprü olarak görmelerine, ideolojinin taşıyıcısı rolünü üstlenmelerine (Halifeoğlu ve Kuzgun, 2016: 68) ve inkılapları merkeze alarak görüşler geliştirmelerine rağmen derginin yayın hayatında kalmasını sağlayamamışlardır.

Kadro Dergisi'nin 34. sayısında imtiyaz sahibi Yakup Kadri Karaosmanoğlu'nun yabancı bir memlekette hükümeti temsil vazifesiyle görevlendirildiği ve bu nedenle yayına bir sonraki sayıdan itibaren ara verileceği (Kadro Dergisi, 1934a: 2); en son sayıda (35-36) ise yayına son verildiği belirtilmiştir (Kadro Dergisi, 1934b: 2). Kadro dergisinde Karaosmanoğlu dışındaki düzenli yazı yazan diğer yazarlar devlet memurudur ve 1931'de çıkarılan Türk Basın Kanunu'na göre memurlar imtiyaz sahibi olamamaktadır. Karaosmanoğlu'nun da diplomat olarak atanması imtiyaz sahipliği sorununa neden olmuş ve dergi yayını durdurulmak zorunda kalınmıştır. Ancak birçok yorumcu Karaosmanoğlu'nun diplomat olarak atanmasının yayınının durdurulması için hazırlanmış bir gerekçe olduğu görüşündedir. Nitekim Karaosmanoğlu da sonradan diplomat olarak atanmasının kendi isteği dışında geliştiğini belirtmiş hatta bunu bir sürgün olarak tanımlamıştır (Türkeş, 1999: 203-204).

Derginin kuruluş aşamasında Karaosmanoğlu dönemin CHP Genel Sekreteri olan Recep Peker'e CHP'nin öncü organı olarak görev yapacak bir dergi çıkarma niyetinden bahsetmiş, olumsuz yanıt almıştır. Buna rağmen Atatürk ve İsmet İnönü'den dergi için izin alınmıştır (Uyguner, 1993: 23). Ancak Peker başta olmak üzere CHP Merkez İdare Heyeti dergiyi sık sık köşke şikâyet konusu olarak taşımıştır. Özellikle yabancı bir sözcük olan "cadre" kelimesinden alınan "kadro" sözcüğü ve dergide yabancı ideolojinin hâkim olduğu şeklindeki düşünce ile devletçilik yorumu eleştirilmiştir (Karaosmanoğlu, 1968: 94-95). Karaosmanoğlu'na göre Peker, parti adına yayın yapma tasarrufunun sadece kendilerinde olmasını istemiştir (Karaosmanoğlu, 1967: 26).

Tek parti rejiminin dişında da eleştirilen Kadro Dergisi'nin kapanmasında farklı nedenler ortaya atılmaktadır. Öne sürülen diğer iddialar şu şekildedir (Ertan, 2003: 27-28): Kadrocuların önermiş oldukları devletçilik fikri, sermaye çevrelerinin hoşuna gitmemiş ve bu çevrenin temsilcisi sayılan İş Bankası grubu derginin kapanması konusunda iktidarı etkilemiştir. Aydemir, kendilerine dönük iki cepheden gelen itirazların olduğunu belirtmiştir. Bunlardan birincisini yazarlar ve araştırmacılar oluşturmaktadır ki Aydemir bunu normal karşılamaktadır. Ancak Kadro'nun kapanmasının nedenini hiç beklemedikleri halde iktisadi cephe olarak görmektedir (Aydemir, 1970: 5). Yine bir başka iddiaya göre İnönü'nün dergiye gönderdiği bir yazıya binaen Siirt Vekili Mahmut Soydan'in dergiyi komünistlikle suçlaması üzerine dergi kapanmıştır. Ancak o dönemde Mahmut Soydan İş Bankası İdare Meclisi Başkanı'dır (Aydemir, 1970: 5). Bu da getirilen eleştirinin yine sermaye çevresinden kaynaklandığını düşündürmektedir. Son olarak derginin tirajının düşmesini de neden olarak öne sürenler bulunmaktadır. Netice itibariyle dergi iktidarın izin ve onayı ile kurulmuş ve bu izin kaldırıldıktan sonra kapanmıştır (Yanardağ, 2012: 153).

\section{Kadro Dergisinde Planlama}

Kadro Dergisi'nde planlama, neredeyse ilişkili olduğu devletçilik kadar önemli ve üzerinde durulan bir konu olmuştur. Kadrocular planlamayı iktisadi devletçilik anlayışı ile ilişkili olarak milli kurtuluş hareketi temelinde savunmuştur ve bu bağlam planlamanın genel çerçevesini oluşturmuştur. Planlama anlayışını genel olarak etkileyen ikinci bir husus da planın ne düzeyde savunulacağıyla ilgilidir. Kadrocular planlama anlayışının Avrupa'da yükselişe geçtiği, her ülkenin kendi özgün koşullarına göre bir plana sahip olabileceği ve Sovyetlerin beş yıllık planlarla Karl Marx'ın öğretilerinden sıyrıldığı şeklinde argümanlarla planlama kavramını sosyalist boyutundan soyutlamaya 
çalışmışlardır (Küçük, 1981: 94-97). Kadrocuların planın yalnızca Sovyetler Birliği'ne ait olmadığı ispatlama çabasında, yukarıda belirttiğimiz eleştirilerin etkisi vardır. Çünkü Kadrocular bir taraftan kapitalist ekonomik yapıyı reddetmekte, diğer taraftan sinıfsız bir toplum tasavvuruyla devletçiliği benimsemektedir. $\mathrm{Bu}$ nedenle planlamayı evrensel bir araç olarak tanımlamaya çalışmaktadırlar. Zaman zaman dağınık bir görünüm algısı verse de aşağıda inceleneceği üzere özellikle kavramın anlamı ve planlamanın önemi ve amacı gibi planlamayı oluşturan sinırlarda netlik söz konusudur.

\subsection{Planlamanın Önemi: Şuurun En Canlı Göstergesi Olarak Plan}

Kadroculara göre Sovyetler Birliği'nde hayat bulan ve Avrupa'da neredeyse "fetişleşmiş" olan plan (Aydemir, 1932a: 5) devletin ana aktörü olması gereken milli iktisadın en temel özelliğidir. Plan, Sovyetler Birliği'nin kurmaya çalıştığ 1 komünist iktisat sistemi ve Akvam Cemiyeti'nin öncülük ettiği kapitalist düzen yerine, daha önce örneği olmayan milli iktisat sistemini kurmaya çalışan Türkiye'nin başvuracağı en önemli metottur (Tör, 1932b: 7-8). Ülke ekonomisinin şuur ve bilgi ile kurulmasının yegâne yolu plandır. Aksi durumda, iktisadi hayatı "bırakınız yapsınlar, bırakınız geçsinler" şeklinde liberal bir anlayışa terk etmek, zaten geri olan iktisadi hayatın dünyada yaşanan gelişmelerin daha da gerisinde kalmasına sebep olacak ve tekrar sömürgeleşme ihtimalini doğuracaktır (Tör, 1932e: 16). Kadrocular plan konusunun geçtiği her yerde çeşitli şekillerde kavramın önemini vurgulamışlardır.

Sovyetler Birliği'nin planlama anlayışı üzerinden konunun önemini anlatan Karaosmanoğlu, beş yıllık planların uygulandığı bazı alanlarda başarısız sonuçların alındığını, bazılarında ise hedeflerin üstüne çıkıldığını belirtmektedir. Başarısızlıklarına rağmen Karaosmanoğlu akıl, irade ve sistem hareketinin ifadesi olarak tanımladığı planlamayı olumsuz yorumlayanların tarafsız olmadıklarını ifade etmektedir. Ona göre Avrupa'nın, Sovyetler Birliği'nin beş yıllık planlarında başarısız olacakları tezi artık "ya başarılı olurlarsa" korkusuna evrilmiştir. Sovyetler Birliği'nin tekniğinin gelişmesi yalnızca serbest rekabet pazarını altüst etmeyecek ayrıca mevcut krizi derinleştirecektir. Bunun yanı sira komünist rejim itibar kazanacak ve bu da Rus inkılapçılarının en büyük amacı olan cihan inkılabına yol açacaktır. Beş yıllık planlar bu özellikleri nedeniyle sanat ve ticaret planı değil harp ve inkılap planıdır (Karaosmanoğlu, 1932). Karaosmanoğlu bu bakış açısıyla kolektif çalışan işçileri siperlerdeki askerlere, Moskova'yı bir karargâha ve Sovyetler Birliği'ni muharebe halinde bir memlekete benzetilmektedir (Karaosmanoğlu, 1933: 30).

Plan ve savaş arasında bir ilişkinin kurulması Kadrocuların plan konusuna hâkim olduklarının önemli bir göstergesidir. Çünkü planlama pratiği savaş ile olan ilişkiyi doğrulamaktadır. Lenin'in Birinci Dünya Savaşı'ndaki savaş ekonomisinin incelenmesiyle çıkardığı ilkeler, Sovyet planlamasının temel ilkeleri olmuştur. Yine Fransa İkinci Dünya Savaşı'ndan sonra yıkıntıları ortadan kaldırmak için planlamayı devreye koymuştur (Küçük, 1981: 93). Planın önemini anlatırken özellikle Vedat Nedim Tör de bu ilişkiyi kullanarak, planı askeri bir mesele şeklinde ele almıştır. Plan, planlı ve sistemli bir faaliyet olarak nitelendirilen
Dumlupınar Meydan Muharebesi ile aynı görülmektedir. Plan konusuna da aynı sistemle yaklaşmak gereklidir (Tör, 1932b: 7-8). İçinde bulunulan durumu iktisadi savaş olarak tanımlayan kadrocular, askeri seferberlikte olduğu gibi toplumun maddi ve manevi tüm kuvvetlerinin belirli bir plan altında sevk ve idare edilmesini istemektedir (Tör, 1932c: 18). Askeri anlamda ilerlemenin sağlanabilmesi için gerekli olan teknik, bilgi ve kabiliyet nasıl ayrı ayrı, şuurlu ve disiplinli bir yöntem ile düzenlenmişse iktisadi hayat da başıbozukluktan kurtulmalıdır (Tör, 1932d: 17). En az zaman ve emek ile en rasyonel harp tekniğini elde etmek nasıl ki bir planı gerektiriyorsa iktisadi istiklalin korunması için plan şarttır. Bu bakış açısıyla milli iktisat planının yapılması görevini yerine getirecek olan Ali İktisat Meclisi'ne milli iktisadın "Erkanı Harbiye”si denmiştir (Tör, 1933b: 13-14).

Ali İktisat Meclisi'nin Birinci Beş Yıllık Sanayi Planı’nın çalışmalarına başlaması, Kadrocular tarafindan memnuniyetle karşılanmıştır. İktisadi kuruluş yollarının çizilmesi ve iktisat planının hazırlanmasına katkı sunmanın her aydının görevi olduğu belirtilmiştir. Konu ile ilgili fikir beyan etmek ve araştırma yapmak milli bir dava olarak ifade edilmiştir (Aydemir, 1933b: 5-6). Plan hazırlıklarını yüksek bir hamle olarak niteleyen ve bunu saygı ile selamlayan Kadrocular, plan ortaya çıktıktan sonra bunun kısmi bir inşa planı oluğunu vurgulamıştır (Aydemir, 1934b). Sonraki yazılarında, aşağıda planların niteliği başlığında incelenecek olan sektörleri ele alarak kendi pencerelerinden sanayi planına katkı sunmaya çalışmışlardır. Sonuç itibariyle Kadrocular plansızlığı "toplumsal hastalığın" bir unsuru (Aydemir, 1934c: 9): "milli iktisat için korkunç bir buhran" (Kadro Dergisi, 1934c) şeklinde nitelerken; planı, kurtuluş hareketinde cemiyetin "parolası" (Hayrettin, 1933: 57-58): devletin "iktisadi karakteri" (Aydemir, 1934d: 10) ve “şuurun en canlı nişanesi” (Kadro Dergisi, 1933; Tör, 1932b: 9) olarak kabul etmişlerdir.

\subsection{Planlamanın Anlamı: Tanzim Olunmuş Bir İşbirliği Olarak Plan}

Kadrocuların planlama anlayışı sık sık atıfta bulundukları Alman düșünür Werner Sombart'ın görüşünün paralelindedir (Tekeli ve İlkin, 2009: 55). Sombart'a göre planlı iktisat kaotik, düzensiz ve anlamsız iktisadın zıddıdır. Planlı iktisadın üç temel özelliği bulunmaktadır: (i) plan iktisat hayatının bütün parçalarını içine almalıdır (kavrayıcılı). (ii) plan tek bir merci tarafindan düzenlenmelidir (vahdet/birlik). Bu merci milli birliği temsil eden devlettir. (iii) plan mekanik bir şema özelliği göstermez ve her milletin iktisadi ve toplumsal şartlarına göre farklılık gösterir (tenevvü/çeşitlilik). Bu nedenle her milletin kendisine göre iktisat planı olmalıdır (Tör, 1932a: 37-38). Kadrocular Sombart'ın görüşlerinin bir kısmını eleştirseler de planın milli iktisat meselesi olarak görülmesi ve planın temel özellikleri noktasında Sombart'ın görüşlerini kabul etmekte ve bunları yapmış oldukları çalışmalarda referans noktası olarak almaktadırlar.

Kadroculara göre planın iki temel anlamı bulunmaktadır. Rusya için geçerli olan ve bir ihtilal meselesi içinde yer bulan direktif olarak plan, toplumun gidişine dişardan ve şartlara rağmen bir müdahaledir. Buna karşın bir 1slah hareketi olarak tanımlanan ve Avrupa'da gelişen önceden görüş 
olarak plan ise toplumun kapasitesinin ortaya çıkacağı aşamaların önceden izlenip tespit edilmesidir. Bu iki anlam üzerinden kavramı tartışan Aydemir, direktif olarak planda toplum kanunlarına müdahale edilmesi şeklinde bir durum söz konusu olduğu için ilk bakışta kabul edilemez algısı oluşturduğunu belirtmektedir. Çünkü her müdahale, toplumca alışılmış olan temel bir kanununun ortadan kaldırılması ya da inkâr edilmesi şeklinde bir saldırıdır. Aydemir bazı düşünürlerin, plan kavramının bu anlamıyla ilk kez kabul edildiği Rus toplumu için; eğer planın içeriğinde yer alan sektörler arasında bir ahenk yakalanmazsa ekonomik krizin olabileceği görüşünü ileri sürdüklerini belirtmektedir. Örneğin topraktan elde edilen ürün ile sanayi ürün hacmi arasında bir oransızlık olması, üretim yetersizliği anlamına gelecek ve krize neden olacaktır. Plan kavramını orantısızlıkların önceden görülüşü olarak algılayan teorisyenlere göre yetersizlik (âdem-i kifayet), planlamayı müdahale olarak kabul eden ve farklı sektörlerin birbirine uyumunu hesap etmeyen Rus sosyalist iktisadının temelidir. Bu nedenle onlara göre plan, toplum üretim alanları arasında orantılı ve dengeli aşamaların önceden tespit edilmesi ve bunlara göre hareket edilmesidir (Aydemir, 1932a). Birinci anlayışta inkılapların gerektirdiği müdahaleler planı şekillendirirken ikincisinde ise toplumun üretim kapasitesi ve bunun gelişimi belirleyici olmaktadır.

Aydemir her iki düşüncenin de doğru tarafları olduğunu kabul etmekle birlikte Türkiye için planı "tanzim olunmuş bir milli işbirliği”" olarak tanımlamaktadır (Aydemir, 1932a: 8). Kadrocular bu tanımı, planı o dönemde uygulayan Sovyetler Birliği'nin ve plana geçme eğiliminde olan Avrupa'nın plan anlayışından farklı olarak "milli kurtuluş Türkiye'sinin" plan anlayışı olarak kabul etmiştir. Onlara göre plan, ne üretim araçları üzerinde toplumsal mülkiyeti tesis eden bir düzen ne de kâr zihniyetinin belirleyici olduğu üretim kollarının kartelleşmesi veya tröstleşmesi sonucunu doğuracak bir araçtır. İşçi sınıfının başat aktör olduğu birinci seçenekte şahsi sermayenin tasfiyesi; kârın öncelediği ikinci seçenekte milli menfaatler aleyhine şahsi mülkiyetin takviyesi söz konusudur (Tökin, 1932a: 36-37). Kadroculara göre liberal demokrasilerin plan ile doğrudan alakası olmadığı gibi planın sosyalizme mahsus bir şey olarak görülmesi yanlış bir kanıdır ve milli bir rejimde de plan söz konusu olabilir (Aydemir, 1934a: 8). Sömürgeciliğe karşı bir isyan niteliğinde tanımlanan milli kurtuluş hareketlerinde plan, milli yapı içinde mevcut ya da ileride doğabilecek toplumsal çelişkileri milletin menfaati için tasfiye ve bütün milleti kapsayacak bir iş birliği yani ortak bir dava olarak kabul edilmiştir (Tökin, 1932a: 36-37). Bu bağlamda plan, millete iktisadi anlamda ortak gayeler tesbit eden aracin adıdır (Tör, 1933a: 22).

\subsection{Planlamanın Amaci: Ekonomik, Toplumsal ve Siyasi Hedeflerin Aracı Olarak Plan}

Kadro dergisinde planlama sürekli milli kurtuluş hareketi ile ilişkilendirilmiş ve gelişimin gerektirdiği koşulların oluşması ve gerilemeye neden olacak etmenlerin ortadan kaldırılması için planlama önemli bir araç olarak önerilmiştir. 1930'da İktisat ve Tasarruf Cemiyeti'nin öncülüğünde düzenlenen sanayi kongresinde sanayinin gelişimini engelleyen; fabrika yerinin belirlenmesi ve büyüklüğü, girişimcinin sermayeden büyük teşebbüslere girerek borçlanmaya gitmesi, imalat ve satışta yetersiz uzmanlaşma, kâr amacıyla gereğinden fazla aynı tür fabrika açma, malzeme ve ürünlerin niteliğine bakılmaksızın uygun olmayan makinaların alımı gibi sorunlar plansızlığa bağlanmıştır. Kadroculara göre, milli sermayenin israf edilmesini engellemek devletin şuurlu ve planlı mesaisiyle olabilir (Tökin, 1932b: 24-25). Son iki asırdır teknik olarak yaşanan gerilemenin ve Türkiye'yi yarı sömürge haline getiren nedenlerin başında yine tekniğin başıboş bırakılması, yani plansızlık sayılmıştır. Onlara göre, plansızlık dünyayı iktisadi olarak hâkim ve mahkûm (tabi ve metbu) ülkeler şeklinde iki ayrı kategoriye ayıran sömürgeciliğin temelidir. $\mathrm{Bu}$ yüzden Türkiye ve benzeri ülkelerde planlama, iki temel nedene bağlı olarak uygulanmalıdır: (i) genel olarak milletler arasındaki tabiiyet metbuiyet çelişkisinin tasfiye edilmesi ve (ii) millet içinde iktisadi çelişkilerin ve çıkar mücadelelerinin doğmamas1. Kadrocular milli kurtuluş hareketlerinin selametini, rasyonel olmayan bir şekilde gelişen tekniğin ortaya çıkardığı sömürgecilik akımlarının ortadan kalkmasıyla ilişkili görmüştür. Bunun da ancak tekniğin her tarafta planlı olarak denetlenmesiyle olabileceği belirtilmiştir. Millet içinde varolan keskin sınıf mücadeleleri ve krizler gibi toplum bütünlüğünü sarsacak çelişkilerin de yine tekniğin ve iktisadi faaliyetlerin planlanması ile ortadan kalkacağı ifade edilmiştir (Aydemir, 1932a: 10-11). Kadrocular genel olarak ikinci amaç, yani Türkiye açısından planın etkileri üzerinde daha fazla kafa yormuşlardır.

Türkiye'de ileri teknik; büyük üretim tekniği, bu tekniği sağlayacak ferdi sermaye, on dokuzuncu yüzyıl Avrupa'sının sahip olduğu serbest pazar ve sömürgeler gibi koşullar bulunmadığından ancak bir plan dâhilinde kurulabilir. Kadroculara göre, milletin menfaati için yapılacak plan, bütün toplumu düzene koyacak, sevk ve idare edecek, bütün milleti kapsayacak bir işbirliği şeklinde olmalıdır. Bu da ancak devlet eliyle olabilir (Aydemir, 1932a: 11; Tökin, 1932a: 38; Tör, 1933b: 13). Çünkü 19. asırda fertlerin iktisadi hayatta önemli bir aktör olma durumu olmuşsa da ileri tekniğin hâkim olduğu 20. asır, özellikle Türkiye açısından bunun koşullarını taşımamaktadır. İktisadi inkılabın gerçekleşmesi noktasında fertler ancak bir teşkilat ve plan içinde kıymet ifade etmektedir (Tör, 1932: 13).

Kadrocular devletin başat aktör olması gerekliliğini Türkiye'de henüz bulunmayan keskin sınıf mücadelelerinin önüne geçmesi noktasında da önemli görmektedir. Üretim araçlarına sahip olan ve bundan mahrum olanların kavgasının, üretim araçlarının gelişmiş ve yoğun olduğu ülkelerde olduğunu ve bunun zeminini taşımayan Türkiye açısından tekniğin devlet kontrolünde planlı gelişmesi durumunda sınıf çelişkilerinin olmayacağını iddia etmişlerdir (Aydemir, 1932b: 9). Diğer bir ifadeyle, planlı devletçilikle üretim araçlarının devlete tahsisi zaten bir sınıflaşmanın olmadığı toplumsal yapıda sınıflaşmayı imkânsız kılacak ve sınıf mücadelelerinin hâkim karakter olması peşinen engellenecektir. (Belge, 1932a: 38). Bu görüş, Atatürk'ün İzmir İktisat Kongresi'nde ve Cumhuriyet Halk Firkası'nın kuruluşu dolaysıyla yaptığı konuşmalarda Türkiye'de Batı'da olduğu gibi çıkarları birbiri ile çatışan sınıfların bulunmadığı ve kalkınmanın bütün sınıfları bir arada zenginleştiren bir şekilde olması gerektiği söylemiyle paraleldir. Halkçılık anlayışından türeyen bu anlayışa göre bütün halk imtiyazsız, sınıfsız kaynaşmış bir kitledir (Timur, 2013: 118). Kadroculara göre iş ve üretim alanında çalışan zümreler arasında bir menfaat çelişkisi olmayacağı gibi 
devletin tüm halkı temsil etmesi devlet-halk çelişkisini de engelleyecektir (Aydemir, 1934e: 7). Aksi halde devlet 19. asır Avrupa'sının liberal-demokratik yolunu benimsemesi durumunda sınıf mücadelelerinin "bütün acıklı akıbetini" göze almak zorundadır (Aydemir, 1934e: 30).

Kadroculara göre devlet, iktisadi ve siyasi bağımsızlık hedefiyle memleketin planlı bir şekilde yeniden kurulmasında millete karşı aktif bir rol almalıdır (Tökin, 1933a: 30). Bu rol için herhangi bir sınır belirtilmediği gibi inkılaplar için kabulü mümkün olmayan durumlar meşru sayılmıştır. Nitekim Aydemir İstanbul Darülfünunu'nun inkılaplara gereken hassasiyeti göstermediğini ele alan yazısında, Rusya'da inşa planını sorgulayan bir kişinin mahkûm edilmesini şiddet olduğunu ifade etmekte ancak bunu ink1lap hassasiyeti olarak yorumlamakta hatta zorunluluk olarak görmektedir (Aydemir, 1933e: 10). Kadroculara göre inkılapların kapsayıcı olması ve derinleşmesi için plan ve disiplinin bütün iktisadi ve toplumsal işlerde kanunlarla teyit edilmesi gereklidir (Aydemir, 1933b: 5). Sürekli kullandıkları tabirle milli kurtuluş devleti açısından müdahale ve plan hiçbir zaman geçici değildir (Aydemir, 1934d: 11). Sonuç olarak, özellikle devlet iktisadının temel özelliği, yani devletin iktisadi fonksiyonlarının dayanak noktası olarak görülen plan, önemli alanlardaki iktisadi faaliyetleri belirli bir hesap dahlinde düzenlemek ve bu faaliyetlerden mevcut olmayanları meydana getirmek; bununla ilişkili olarak dengeli ve rayonel bir şekilde gelişmek ve dünya ekonomisi içinde yer edinmek; sınıf çelişkilerini ortadan kaldırmak ve inkılaplar temelinde toplumsal bir zihniyet kurmak şeklinde ekonomik, toplumsal ve siyasi hedeflere varılması noktasında önemli bir araç olarak görülmüştür (Tör, 1932d; Tör, 1933b: 13; Hayrettin, 1933: 57; Aydemir, 1933b: 5; Aydemir, 1934f: 42).

\subsection{Planın Kapsamı: İş Planı ve İş Bölümü Temelinde Sektörel Haritalandırma Olarak Plan}

Kadrocular inkılapların gerektirdiği amaçlar için zorunlu bir yol olarak gördükleri planlamanın sadece bu boyutu ile değil, ayrıca sektör olarak neleri kapsamayacağı ve kapsayacağı alanların nasıl planlaması gerektiği üzerine de çalışmışlardır. Sombart'in öne sürdüğü görüşe dayanarak Kadrocular, toplumun bütün iktisadi unsur ve faaliyetlerinin tamamen plan içine alınamayacağını belirtmektedirler. Plan genel olarak ülkenin başlıca iktisadi alanlarında faaliyette bulunan ve iktisadi sistemin gidişatına etkisi olabilecek ve bunun kapsamını belirleyecek iktisadi kolları düzenlemeli veya kurmalıdır. Düzene sokulması halinde iktisadi açıdan kıymet ifade etmeyen küçük sanayi, perakende zirai teşebbüsler, esnaf faaliyetleri gibi alanların plan içine alınmaması gerektiği ifade edilmiştir (Aydemir, 1932a: 9). Örneğin el sanayiyi ortaçağ ve gelenekçi üretim tarzının mirası olarak gören Kadroculara göre, planlama içinde bu tür faaliyetlerin geleneksel üretim yöntemleri tasfiye edilecek ve bunlar büyük teknikli üretim içinde kaynayacaktır (Tökin, 1932c: 24).

Planın kapsayacağı iktisadi alanların başında ileri teknik, uzmanlaşma ve büyük sermaye gerektiren sanayi gelmektedir (Tör, 1932g: 15). Özel teşebbüsleri de kapsaması, aynı sanayi kollarında zarar verecek rekabet mücadelelerinin önlenmesi, gelişme potansiyeli olan sanayi kollarının seçilmesi, gerekli sanayi alanlarının tespiti, kurulum için öncelik ve yer tespitinin yapılması sanayi planı için yapılan temel önerilerdir (Tör, 1932c: 17-18). Dergide üzerinde durulan sanayi kollarının başında şeker ve dokuma sanayi gibi planlaştırılması ve kontrolü ilk etapta daha kolay olan alanlar gelmektedir (Aydemir, 1932c: 11; Tör, 1932g: 15). Ancak Kadrocular sanayi planının tek başına yeterli olmayacağını, bunun ziraat ve diğer alanlarda da planlamayı zorunlu kıldığını belirtmektedirler. Örneğin dokuma sanayi pamuk ve kendir ziraatı ile ilişkilidir. Bunun gibi buğday için alınan bir tedbir sanayi, kredi ve sermaye alanlarını da zaman için de etkileyeceğinden genel bir planın koşullarına zemin hazırlayacaktır. $\mathrm{Bu}$ nedenle sektörler arasında gelişmenin ahenkli bir şekilde olabilmesi, ilişkili sektörlerin de planlanmasını gerektirmektedir. Sanayi ve ziraat başlıcası olmakla birlikte kredi, ulaşım, enerji, maliye gibi birçok alanın planlanması gerektiğini, bazen konuyu detaylı ele alarak bazen de değinerek vurgulamışlardır (Kadro Dergisi, 1934d: 35; Tör, 1932c: 15; Belge, 1932b: 31; Tör, 1934a: 13; Aydemir, 1934f: 41; Yazman, 1933: 46; Aydemir, 1933c: 10; Tör, 1933c: 18; Tör, 1934b: 26). Bu nedenle 1934'te kabul edilen Birinci Beş Yııllı Sanayi Planı yukarıda açıklandığı gibi önemli görülmekle birlikte zirai üretim, dağ sanayi, ulaştırma, kredi, dış ticaret ve uzman kadronun hazırlanması gibi tüm iktisadi faaliyetleri içine almadı $\breve{g}_{1}$ için inşa planı olarak nitelendirilmiştir. Hatta plan yerine program kavramı kullanılmış ve başlangıç olarak görülen bu programı bir iktisat planının takip etmesi gerektiği ifade edilmiştir (Aydemir, 1934b: 5; Tökin, 1934: 30).

Kadrocuların planlama konusunda üzerinde durdukları önemli diğer iki konu; beşeri sermaye dâhil bütün kaynakların içinde yer alacağı ve düzenleneceği iş planı ve ülke genelinde iş bölümünün yapılacağı ihtisaslaşmadır. İş planındaki amaç iş kabiliyetini realize etmektir. İçine alınmasında fayda ve zaruret bulunan her şeyin iş planında bir yeri olduğu belirtilmiştir. Mevcut işler ve bu işleri yapacak emeği ihtiva edecek iş planı, ülkedeki iş kabiliyetini ortaya çıkaracaktır. Buradaki amaç toplumsal iş bölümünün sağlanmasıdır (Aydemir, 1932d; Aydemir, 1932e: 12). Özellikle Aydemir'in üzerinde durduğu ve Sovyetler Birliği'nden esinlenerek ortaya attığı ikinci konu, coğrafi temelde ihtisaslaşmadır (rayonlaşmadır). Rayon kavramı, belirli üretim alanlarında uzmanlaşmış saha için kullanılmıştır. $\mathrm{Bu}$ sahada doğal şartlar, iktisadi nitelikler, nüfus yoğunluğu, nüfusun uzmanlık alanlarına göre dağılımı vb. sahaya ait özellikler haritalandırılmalıdır. Çıkarılan harita ile her sahanın hangi alanda uzmanlaşması gerektiği ortaya çıkarılacaktır. Böylece ülke iktisadi mıntıkalara ayrılacaktır. Aydemir, Türkiye'de İktisat Vekalet'ince illerin sıralanabilmesi için kullanılan bir iktisadi mıntıka ayırımı olduğunu belirtmiş, ancak bunun ne coğrafi ne de iktisadi bir kaygıyla yapılmadığını ifade etmiştir. Aydemir'e göre rayonlaşma farklı şekillerde olabilir: (i) Rayonlaşma tütün sahalarının tespiti gibi tek bir madde ya da dokuma fabrikalarının haritasını çıkarıp yoğunlaşmayı hesaplamak şeklinde yalnız bir iktisadi konu üzerinden olabilir. (ii) Rayonlaşma, köy iktisadı gibi tek bir iktisadi şube esas alınarak da yapılabilir. (iii) Aydemir'in desteklediği üçüncü tür, mevcut ve gelecekteki iktisadi bütün alan ve faaliyetleri içine alan rayonlaşmadır. Yapılması güç olan bu tür bir rayonlaşma ancak inkılapçı bir anlayışla, belirli bir hesap ve plan dâhilinde öncelikli olarak gündeme alınmasıyla yapılabilir. Aydemir, iktisadi rayonlaşmanın devletçi 
iktisadın tezi olduğunu ve farklı iş sahaları için ayrı ayrı yapılacak iktisadi planlar olmaksızın devlet iktisat planının düşünülemeyeceğini belirtmiştir (Aydemir, 1933d).

\section{Sonuç}

1930'lar Sovyetler Birliği'nin beş yıllık planlar ile ilerleme kaydederken, 1929 Dünya Ekonomik Bunalımı nedeniyle genel olarak dünyanın çözüm bekleyen sorularla karşı karşıya olduğu yıllardır. Krizin en çok vurduğu sanayileşmiş ülkeler, Sovyetlere ait bir araç olarak nitelendirdikleri planlamayı kullanmamaya direnmişlerse de İkinci Dünya Savaşı'ndan sonra Avrupa'nın savaş yıkıntılarını ortadan kaldırmak istemesi ve kurumsallaşan refah devleti uygulamalarının devlet müdahaleciliğine zemin hazırlaması planlamayı bu ülkelerin gündemine koymuştur. Batılı ülkeler ekonominin yeniden canlanması için kalkınma planları hazırlamıştır. Bunda Sovyetler Birliği'nin İkinci Dünya Savaşı'ndan güçlü bir ülke olarak çıkmasının planlama ile ilişkilendirilmesinin de payı vardır (Sezen, 1999). Türkiye ise bu ülkelerden çok daha önce 1930'larda plan çalışmaları yapmıştır. Dünya krizi Türkiye'yi içe kapalı bir duruma iterken, ekonomik anlamda gelişimin sağlanmasını ülkenin kendi koşullarında aramaya zorlamıştır. Sorunların çözüm yöntemi olarak planlama, bir taraftan dönemin benimsenen devletçilik anlayışının aracı olarak iktidar gündemine girerken, diğer taraftan aydınlar arasında üzerinde tartışılan bir konu olmuştur.

Türkiye'de 1930'larda iki sanayi planı yapılmıştır. Birinci plan başarıya ulaşırken, ikinci plan İkinci Dünya savaşı nedeniyle uygulanamamıştır. Özellikle İkinci Beş Yıllık sanayi planı özelinde, o dönemde hiçbir ülkede bu nitelikte bir sektör planı bulunmamaktadır (Ölçen, 1982: 145-146). Ancak bu planlar ilgili literatürde bazı yazarlar tarafindan makro plan niteliği taşımadığı için plan kavramı içerisinde değerlendirilmemektedir. Getirilen eleştirilerde haklılık payı bulunmaktadır ve planlar günümüz planları ile karşılaştırıldığında kapsamlı değildir. Ancak bu Türkiye'nin erken dönem plan pratiği ile sınırlıdır ve anlayış olarak planlama oldukça geniş bir anlamda tasavvur edilmiştir.

Kadro Dergisi yazarları plan anlayışını geniş kapsamda ele alan ilk düşünürlerdir. Planlamayı doğrudan ve ilişkili olduğu konular üzerinden ele alan çalışmalarla derginin tüm sayıları boyunca planlama konusu dergi gündeminde yer almıştır. Kadrocular inkılapların başarıya ulaşması için planlamayı önemli görmekte, devletçilik görüşünün ancak planlamaya dayanılarak başarıya ulaşacağını savunmaktadırlar. Nitelik olarak katma değeri düşük sektörler haricinde tüm sektörleri kapsayacak bir plan önerisinde bulunan Kadroculara göre, plan milli kurtuluş hareketini tamamlayan önemli bir araçtır. Bunun yanı sıra planın önemli görülen yönlerinden birisi de toplum için ortak amaçlara iştiraki sağlayarak milli birliğe hizmet etme düşüncesidir. Bu bağlamda Kadro Dergisi'nde plan derginin kuruluşunda benimsenen inkılapların derinleşmesi ve benimsenmesi rolüne hizmet edecek önemli bir araç olarak tasarlanmıştır.

Planlama anlayışı yalnızca ekonomi ya da onunla ilişkili alanlar üzerinden değil, istenilen toplumsal zihniyet ve biçimin oluşturulması için sosyolojik; şehirlerin modern olarak tasarlanması için kentsel; sağlıklı ve yapıcı bir edebiyat için sanatsal bağlamlarla da ele alınmıştır
(Aydemir, 1934f; Tör, 1933d; Karaosmanoğlu, 1934a; Karaosmanoğlu, 1934b). Kadrocular planı tüm topluma nüfuz edecek bir olgu olarak düşünmüş, herkesin alakasını celp etmesi gereken milli bir dava olarak görmüş ve nihayetinde bir kültür haline gelmesini savunmuşlardır. Sonuç olarak, Kadro Dergisi'nde planlamanın ele alınışı üzerinden, Türkiye'nin planlama anlayışının oldukça ileri düzeyde olduğu söylenebilir. Nitekim sanayi sektörü esas alınarak yapılan ilk iki planın, dönemin diğer ülkeleriyle karşılaştırıldığında, Türkiye'nin özgün yönünü oluşturması bunun göstergesidir. Ancak İkinci Dünya Savaşı ağır sanayi temelinde tasarlanan İkinci Beş Yıllık Plan'ın uygulanmasının önüne geçerken, uygun koşulların oluşmayışı nedeniyle mevcut olan ileri ve kapsamlı plan anlayışından da faydalanılmamıştır. 1946'da İvedili sanayi Planı ile bu tarihi firsat bir kez daha kaçırılmıştır. Şevket Süreyya Aydemir ve İsmail Hüsrev Tökin 1946 planında belirlenen politikalara büyük oranda etki etmişlerdir (Tekeli ve İlkin, 1979-1980: 290). Ancak plan 1930'ların devletçi kalkınma politikasını andırdığı için ABD'nin etkisiyle reddedilmiştir. Sanayi yerine tarımı merkeze alan 1947 İktisadi Kalkınma Planı yapılmıştır (Övgün, 2010: 171-172). $\mathrm{Bu}$ plan da uygulanmamış ve yeni bir plan için 1960'lar beklenmiştir.

\section{Kaynakça}

Aydemir, Ş. S. (1932a). Plan Mefhumu Hakkında. Kadro Aylık Fikir Mecmuast, 5, 5-12.

Aydemir, Ş. S. (1932b). Milli Kurtuluş Hareketlerinin Ana Prensipleri. Kadro Aylık Fikir Mecmuası, 8, 6-12.

Aydemir, Ş. S. (1932c). Şeker İstikâli ve 160,000 Ton Türk Şekeri, Kadro Dergisi. Kadro Aylık Fikir Mecmuası, 11, $5-16$.

Aydemir, Ş. S. (1932d). İş hasreti ve 500.000.000 Liralık Türk Bütçesi. Kadro Aylık Fikir Mecmuası, 9, 4-10.

Aydemir, Ş. S. (1932e). İçpazar ve İktisatta ((bütün))lük. Kadro Dergisi Aylık Fikir Mecmuası, 10, 5-12.

Aydemir, Ş. S. (1932f). Geri Teknik ve Say'in Sefaleti. Kadro Aylık Fikir Mecmuası, 6, 9-12.

Aydemir, Ş. S. (1933a). Fikir Hareketleri Arasında Türk Nasyonalizmi. Kadro Aylık Fikir Mecmuası, 18, 5-14.

Aydemir, Ş. S. (1933b). Milli İktisat Plânı ve Şeker Sanayiimiz. Kadro Dergisi Aylık Fikir Mecmuası, 24, 516.

Aydemir, Ş. S. (1933c). Beynelmilel Fikir Hareketleri Arasında Türk Nasyonalizmi. Kadro aylı Fikir Mecmuast, 21, 5-14.

Aydemir, Ş. S. (1933d). Darülfünun İnk1lâp Hassasiyeti ve Cavit Bey İktisatçılığı. Kadro Aylık Fikir Mecmuası, 15, $5-12$.

Aydemir, Ş. S. (1933e). Darülfünun İnk1lap Hassasiyeti ve Cavit Bey İktisatçılığı. Kadro Aylık Fikir Mecmuası, 14, 5-11.

Aydemir, Ş. S. (1934a). Sosyal Milliyetçiliğin Zaferi. Kadro Aylık Fikir Mecmuası, 35-36, 8-22. 
Aydemir, Ş. S. (1934b). Yürüyen Devlet. Kadro Aylık Fikir Mecmuası, 25, 5-12.

Aydemir, Ş. S. (1934c). 1789 İhtilalinin Mezarı Başında. Kadro Aylık Fikir Mecmuası, 33, 4-10.

Aydemir, Ş. S. (1934d). Yeni Devletin İktisadi Fonksiyonları. Kadro Aylık Fikir Mecmuası, 29, 5-14.

Aydemir, Ş. S. (1934e). İş Kanunları Yeni Cemiyetin Temel Kanunlarından Biridir. Kadro Aylık Fikir Mecmuası, 30, 6-15.

Aydemir, Ş. S. (1934f). İçtimaî Zihniyet. Kadro Aylık Fikir Mecmuast, (31): 42-42.

Aydemir, Ş. S. (1970, 11 19). Kadro'yu Atatürk ve İnönü Teşvik Etmişti. Milliyet Gazetesi.

Aydemir, Ş. S. (2011). Kadro ve Ínkılap. İstanbul: Remzi Kitabevi.

Belge, B. A. (1932a). Faşizm ve Türk Milli Kurtuluş Hareketi. Kadro Aylık Fikir Mecmuası, 8, 36-39.

Belge, B. A. (1932b). Rejimler Nasıl Değişiyor? Kadro Aylık Fikir Mecmuası, 12, 27-32.

Demirci, F. (2006). Kadro Hareketi ve Kadrocular. Dumlupınar Üniversitesi Sosyal Bilimler Dergisi, 15, 3554.

Ertan, T. F. (2003). Kadro dergisi Niçin Kapandı? Atatürk Dergisi, 3(4), 19-34.

Gülalp, H. (1993). Kapitalizm Sinfflar ve Devlet. İstanbul: Belge Yayınları.

Günçe, E. (1981). Türkiye'de Planlamanın Dünü-BugünüYarını. ODTÜ Gelişme Dergisi, Özel Sayı, 117-132.

Halifeoğlu, M., \& Kuzgun, M. (2016). Kadro Hareketinin Organik Aydın Yaratma 'Ülküsü'. Amme İdaresi Dergisi,, 49(4), 65-84.

Hayrettin, T. (1933). Ayarlı Milet ve Plan. Kadro Aylık Fikir Mecmuası, 18, 54-58.

İnan, A. (1972). Devletçilik Illkesi Türkiye Cumhuriyetinin Birinci Sanayi Planı 1933. Ankara: Türk Tarih Kurumu Basımevi.

İnan, A. (1989). Türkiye Cumhuriyetinin İkinci sanayi Plant. Ankara: Türk Taarih Kurumu Basımevi.

Kadro Dergisi (1932). Kadro Aylık Fikir Mecmuası, 1, 3-3.

Kadro Dergisi (1933). Kadro Aylık Fikir Mecmuası, 19.

Kadro Dergisi (1934a). Kadro Aylık Fikir Mecmuası, 34, 2 2.

Kadro Dergisi (1934b). Kadro Aylık Fikir Mecmuası, 35-36, 2-2.

Kadro Dergisi (1934c). Kadro Aylık Fikir Mecmuası, 25.

Kadro Dergisi (1934d). Kadro Aylık Fikir Mecmuası, 31, 15 15.

Kansu, G. (2004). Planlı Yıllar. İstanbul: İş Bankası Kültür Yayınları.

Karaosmanoğlu, Y. K. (1932). Ankara Moskova Roma. Kadro Aylık Fikir Mecmuast, 12, 34-35.
Karaosmanoğlu, Y. K. (1933). Ankara Moskova Roma. Kadro Aylık Fikir Mecmuası, 13, 29-31.

Karaosmanoğlu, Y. K. (1934a). Moskova edebiyat Kontrasında. Kadro Aylık Fikir Mecmuası, 33, 27-32.

Karaosmanoğlu, Y. K. (1934b). Sovyet Edebiyatı. Kadro Aylık Fikir Mecmuasl, 35-36, 28-34.

Karaosmanoğlu, Y. K. (1967). Zoraki Diplomat. Ankara: Bilgi Yayınevi.

Karaosmanoğlu, Y. K. (1968). Politikada 45 Yll. Ankara: Bilgi Yayınevi.

Karlı, İ. (2015). Türkiye Cumhuriyeti'nin Kuruluş Döneminde Kadro Dergisi'nin İdeolojik Tasarımı. Siyaset, Ekonomi ve Yönetim Araştırmaları Dergisi, 3(4), 139-160.

Kazanc1, M. (2009). Özgün ve Yerli Bir Hareket Olarak Kadro ve İdeolojisi. Tarih Okulu, 3, 41-58.

Kepkep, N. (1983). "Kadro" Hareketi Açısından Kemalist İdeoloji. Prof. İbrahim Yasa'ya Armağan , (43-56). içinde Ankara: Ankara Üniversitesi siyasal Bilgiler Fakültesikadro.

Küçük, Y. (1981). Türkiye'de Planlama Kavramının Gelişimi Üzerine. ODTÜ Gelişme Dergisi, Özel Sayı, 79115.

Orhan, A. (2009). Tek Partili Yılların Ekonomi-Politiği ve Kadro Hareketi. Kocaeli Üniversitesi Sosyal Bilimler Enstitüsü Dergisi, 17, 120-147.

Ölçen, A. N. (1982). 1923-1938 Döneminde Birinci ve İkinci Sanayi Planları. Atatürk Dönemi Ekonomi Politikası ve Türkiye'nin Ekonomik Gelişmesi, (133-150). içinde Ankara: AÜ SBF Yayınları.

Övgün, B. (2010). Devlet ve Planlama. Ankara: Siyasal Kitabevi.

Sezen, S. (1999). Türkiye'de Planlama. Ankara: TODAİE Yayınları.

Soyak, A. (2013). İktisadi Planlama ve Türkiye Deneyimi. İstanbul: Der Yayınları.

Tekeli, İ., \& İlkin, S. (1979-1980). İkinci Dünya Savaş1 Sırasında Hazırlanan Savaş Sonrası Kalkınma Plan ve Programları. ODTÜ Gelişme Dergisi, Özel sayı, 289325.

Tekeli, İ., \& İlkin, S. (2009). Uygulamaya Geçerken Türkiye'de Devletçiliğin Oluşumu. İstanbul: Bilge Kültür sanat.

Timur, T. (2013). Türk Devrimi ve Sonrast. Ankara: İmge Kitabevi.

Tökin, İ. H. (1932a). Plan Mefhumu Hakkında. Kadro Aylık Fikir Mecmuası, 7, 36-43.

Tökin, İ. H. (1932b). Milli Sermaye Hareketi. Ayllk Fikir Mecmuast, 10, 20-25.

Tökin, İ. H. (1932c). Türkiye El-Sanayii. Kadro Aylık Fikir Mecmuası, 5, 19-24.

Tökin, İ. H. (1933a). Milli Kurtuluş Devletçiliği. Kadro Aylık Fikir Mecmuası, 19, 23-31. 
Tökin, İ. H. (1934). Beş Senelik Programın Manası. Kadro Aylık Fikir Mecmuası, 27, 26-30.

Tör, V. N. (1932a). (Kadro)yu Teyit Eden Bir Eser. Kadro Aylık Fikir Mecmuası, 5, 37-38.

Tör, V. N. (1932b). Müstemleke İktisadiyatından Millet İktisadiyatına. Kadro Aylık Fikir Mecmuası, 1, 6-9.

Tör, V. N. (1932c). Niçin ve Nasıl Sanayileşmemiz Lazım. Kadro Aylık Fikir Mecmuası, 6, 13-18.

Tör, V. N. (1932d). Mefhum Teşkilâtı Değil Madde Teşkilatı. Kadro Aylık Fikir Mecmuası, 8, 13-17.

Tör, V. N. (1932e). İktisat islerinde Devlete Veto hakk1 ve İktisat Vekâleti. Kadro Aylık Fikir Mecmuası, 10, 13-19.

Tör, V. N. (1932f). Müstemleke İktisadiyatından Millet İktisadiyatına. Kadro aylık Fikir Mecmuası, 2, 9-14.

Tör, V. N. (1932g). Değişen Cihan Münasebetleri İçinde Türkiye. Kadro Aylık Fikir Mecmuası, 5, 13-18.

Tör, V. N. (1933a). İktisatta İstiklal. Kadro Aylık Fikir Mecmuasi, 22, 14-18.

Tör, V. N. (1933b). Türk İktisadiyatının Erkânı Harbiye Dairesi: Âli İktisat Meclisi. Kadro Dergisi, 14, 12-17.

Tör, V. N. (1933c). Devletçi Bir Ziraat siyasetinin Ana Prensipleri. Aylık Fikir Mecmuası, 20, 12-19.

Tör, V. N. (1933d). Şehirlerimizin Güzelliğini Zevksiz Ev Sahiplerinin Tecavüzünden Kurtarmalıyız! Kadro Aylık Fikir Mecmuası, 20, 47-48.

Tör, V. N. (1934a). Kömürde Devletçilik. Kadro Aylık Fikir Mecmuası, 25, 13-20.

Tör, V. N. (1934b). Sanayi Planından Sonra Ziraat Planı. Kadro Aylık Fikir Mecmuası, 35-36, 23-27.

Türkeş, M. (1999). Kadro Hareketi. Ankara: İmge Kitabevi.

Tüysüzoğlu, G. (2011). Kadro Hareketi ve Kadrocular. Giresun Üniversitesi Sosyal Bilimler Enstitüsü, 23, 1931.

Uyguner, M. (1993). Yakup Kadri Karaosmanoğlu. Ankara: Bilgi Yayınevi.

Yanardağ, M. (2012). Kadro Hareketi. İstanbul: Destek Yayınevi.

Yazman, M. Ş. (1933). Elektrikli Türkiye. Kadro Aylık Fikir Mecmuası, 16, 42-46. 